Brunton, for they find that if the presence of amyl nitrite is confined to the vessels of the brain alone, a fall of pressure does not take place, but it does occur if blood containing the nitrite circulates in the peripheral vessels of the body, even though the access of any nitrite to the brain is prevented. They likewise find that nitrites are capable of influencing vessels in the area supplied by the splanchnic nerves after section of these nervesanother proof that the action of the nitrites is peripheral.

The part which the group NO. plays in its fatty compounds they have sought to determine by ascertaining quantitatively the comparative amount of influence which each nitrite exerts on blood pressure, pulse frequency, and respiration, when introduced into the circulation of anxsthesised cats, by inhalation or by injection into the arterial or venous system, and also by ascertaining the comparative effect of paraffinic nitrites on the pulse frequency in man.

The quantitative method is doubtless open to some fallacies, but from the extreme care which has manifestly been taken in conducting the experinments, and the laborious manner in which they have been repeated, it seems certain that the results are in the main reliable. With regard to the influence of the nitrites in accelerating the beat of the heart, it is shown that physiological activity increases with molecular weight; amyl nitrite is more powerful than butyl nitrite, butyl than propyl, and so on, methyl being the weakest of all.

The order in which the paraffinic nitrites reduce blood pressure in amount is somewhat, though not quite the same, as that in which they accelerate the pulse, but important exceptions occur, especially in the case of methyl nitrite, which occupies a higher position as a pressure reducing agent than it does as a pulse accelerator. On the other liand, as regards duration of subriormal pressure, the order is quite altered, the nitrites which depress blond pressure to the greatest extent acting for the most part for the shortest time.

The authors have also endeavoured to determine the comparative influence of the various nitrites on striated muscle by exposing the excised gastrocnemius and triceps muscles of frogs to equal quantities of their vapours, and recording the extent and duration of contraction produced with or without electric stimulation. This method is open to the objection that hydrolysis of nitrite vapours occurs very rapidly in the presence of aqueous vapour, nitrous acid being produced. Now, muscle tissue is very susceptible to the influence of acids, and it seems by no means certain that the contractions recorded may not have been in part, at least, due to the acid evolved from the nitrite decomposition. With one exception (propyl nitrite) it was noted that the nitrites with low molecular weight were the lcast powerful in causing muscle contraction, but they acted for the longest time.

Concerning the effects which constitution of the molecule apart from composition has, it was noted throughout that when the effects of primary, secondary, and tertiary nitrites having the same composition were compared, the secondary nitrite was found to have a more powerful influence on pulse acceleration, blood pressure, and miscular contraction than the primary, and the tertiary than the secondary.

The fact that the acceleration of the heart caused by the various fatty nitrites increases with their molecular weight indicates, as the authors justly assume, that the quickening action on the pulse cannot be simply conditioned by the amount of nitroxyl in their molecules, even though it may be true that the nitroxyl group itself quickens the heart's action, for the molecule of methyl nitrite, which is the least effective, contains the largest amount of $\mathrm{NO}_{3}$, whilst that of amyl nitrite, which most powerfully accelerates the heart's action, contains less $\mathrm{NO}_{2}$ than any of the other nitrites examined. A similar conclusion is drawn with regard to the influence of the nitroxyl element in causing lowered blood pressure. It is further pointed out, that the preponderance of the hydrocarbon molecules in the higher nitrites is not necessarily the cause of their increased influence in quickening the pulse and lowering pressure. There are other possible causes. After considering some of these the authors express their opinion that the more marked effect of the nitrites having the largest molecules but containing the smallest amount of $\mathrm{NO}_{2}$ is due to their decreased chemical stability. They incline apparently to the view that the actual molecules of the paraffinic nitrites do not accelerate the heart's action and lower tension, and give reasons for believing that they may actually retard the rapidity of the heart's beat. When, however, the molecule is broken up, the nitrite element becomes active, entering, perhaps, into loose combination with hxmoglobin and certain tissues before it is finally oxidised and eliminated.

The lower combinations, such as ethyl and methyl, being, as they suppose, least easily broken up, exercise least power; on the other liand, for the same reason they act for a longer time, both in lowering tension and con. tracting striated muscle.

To the greater instability of secondary as compared with primary, and of tertiary as compared with secondary nitrites, they attribute their respectively greater poiver, rather than to the fact that in the secondary and tertiary: compounds one and two methyl groups are respectively: attached to the carbon combination of the nitroxyl group. Much remains to be done before the inferences drawn from the elaborate investigations, the results of which have been presented to the Royal Society, can be regarded as definitely proved; but this paper adds, in an important manner, not only to our knowledge of the action of the nitrites, but to our comprehension of the manner in which chemical agents influence the tissues, and become of therapeutic value.

\section{THE LATE PROFESSOR J. P. COOKE.}

THE death of Prof. J. P. Cooke was briefly announced in these columns on September 13 . The following particulars, for which we are indebted to an obituary notice in the Tribune of Cambridge, U.S.A., will be read with melancholy interest by the scientific world :--

Josiah Parsons Cooke was born in Boston, October 12, IS27. He was prepared in the Boston schools, and entered Harvard College in 1845 , graduating three years later. In the following year he was appointed an instructor, and, in IS $5 \mathrm{I}$, Erving professor of mineralogy and chemistry, and director of the chemical laboratory of Harvard University. a post he held until his death.

At the time Prof. Cooke entered upon his duties as head of the chemical depariment at Harvard, the methods of instruction were of the most rudimentary sort. Students in chemistry were required only to hear so many lectures; work in the laboratory was thought unnecessary, its place being taken by the few experiments which the lecturer saw fit to perform before his classes. Now the chemistry courses at Harvard, as at all other American colleges, consist almost entirely of laboratory work. The credit for this change is due very largely to Prof. Cooke.

Prof. Cooke was made an LL.D. by the University of Cambridge in $\mathbf{1 8 8 2}$, and received the same degree from Harvard in 1889 . He was a Fellow of the American Academy and a Member of the National Academy of Science. He was a popular lecturer, and delivered several courses at the Lowell Institute, one of the bestremembered being that given in 1887 on the "Necessary Limitations of Scientific Thought."

He was the author of a number of books, pamphlets, and scientific papers. Perhaps the best known of his

NO. 1301 , vOL. .50] 
books was his "Reigion and Chemistry," published in $\mathrm{I} 864$, which maintained that the designs of a higher intelligence were to be discovered in the province of chemistry. Among other books were: "The New Chemistry," and its companion volume, "Laboratory Practice," reviewed in NATURE, vol. xlvi. p. 99, "The Elements of Chemical Physics," "The Principles of Chemical Philosophy," and "Scientific Culture."

Prof. Cooke was a highly cultivated man. whose attention was directed to many things outside of his own profession. One of his last published papers was written to recommend that scientific men should be educated more broadly. He did not believe in an exclusively scientific education.

His funeral on September 6 was attended by a group of men and women, whose mere presence was the highest compliment that could be paid to the memory of any man. The successors of Longfellow, Lowell, and the brilliant coterie, with which Prof. Cooke was so lnng a part, were glad of the opportunity to show their love and respect for the man who was all but the last of his generation, there being only a very few of his earlv contemporaries left.

Among the well-known people present were President C. IV. Eliot, Profs. H. B. Hill, IV. IV. Goodwin, Francis J. Child, Josiah Royce, C. L. Jackson, G. A. Bartlett, Edward Cummings, Ira N. Hollis, Dr. Samuel A. Green, Prof. William IVatson (one of the secretaries of the American Academy of Arts and Sciences, of which Prof. Cooke was president), Dr. Henry P. Wolcott, and Dr. Benjamin E. Cotting.

\section{NOTES.}

Mr. FRANK, MCCl.EAN, writing to Dr. Gill, under date of August 10, has expressed his desire to present a large equa. torially mounted telescope, equipped ior photographic and spec. troscopic work, to the Royal Observatory at the Cape of Good Hope, With this object he has arranged with Sir Iloward Grubb for the construction of a photographic refracting telescope of $2 f$ inches aperture, and for an object-glass prism to work with it, having a refracting angle of $7 \frac{1}{2}$ degrees and the same aperture as the object-glass. The glass for the objectglass and prism have already been secured, and the definitive order for the instrument was given to Sir Iloward Grubb on May 4 last. Coupled with the photographic telescope there is to be a visual refracting telescope of is inches aperture. The mounting is to be sufficiently elevated to allow a slit spectro. scope, for the determination of stellar motions in the line of sight, to be altached to the photographic telescope, and the gift will include such a spectroscope, as well. as an observatory of light construction. Subject to the concurrence of the Lords Commissioners of the Admiralty, Dr. Gill has cordially and gratefully accepted this noble gift to the Cape Observatory.

Cart. W. J. WhakTox, the hydrographer of the Admiralty, has sent us a copy of a report, drawn up by Mr. P. IV. BasieltSnith, on the results of dredgings obtained on th: great bank known as the Macclesficld Bank, in the China Sea. It may safely be asserted that never before has the biological condition of a sunken coral reef in mid.sed been so completely explored. One of the general results of the whole examination, hydrographical and zoological, is that on the whole of the two hundred miles forming the periphery of the bank, there exists a rim of coral in luxurious growth, and at a remarkably even depth below the surface of from ten to fourteen fathoms. Capt. Wharton points out that this eren. ness of depth is the most striking feature of the chart, and when the great distances are considered, this appears to be a NO. J3OI, VOL. 5O] strong argument ag tinst any movement of the hottom since the a:oll for $n$ was as:umed. It is at any rate quite evident that from the present time onwards no movement is necessary in order to form in the future a perfect atoll, the simple growth of the coral on the rim sufficing; and that we may have here an instance of a suitable original foundation for an atoll so formed, as pointed out by Mr. Darwin. Mr. Bassctt-Smith s examin. ation of the specimens was necessarily very cursory, and it is to be hoped that the mass of material collecled may be thoroughly investigated by skilled zoologists at the IBritish Museum, that full value may be obtained for the labour bestowe.t upon these examinations. The work is so admirable, and the results so important, that we shall return to the subject in a future isisus.

AT several London and provincial medical schooli, on Monday last, the opening of the winter session was made the occasion for introductory addresses to the students. Dr. Isambard Owen, at St. George's Hospital, discoursed chiefly on the importance of mental training in medical study. He renarked that the method of the physician was the method ordinarily employed in all fornis of physical investigation. Science consisted of soundly.dratwn conclusions based upon accurately-made observations. Accurate observation was the foundation of all medical work; and Dr. Owen dwelt at some length on the fallacies of ordinary observation, and the scrupu. lous care needed to ensure exactitude. At St. Thomas's Hospital, the Rev. W. W. Merry delivered an address mainly concerned with Plato's criticism; upon the practice of medicine and surgery in Homeric times. Mr. G. Ilartridge offered practical counsel to the students at Westminster Hospital, and, as an inducement to work, remarked that "the Royal Socicty num. bers amons its members a large proportion of medical men, a much larger number than all the other professions put together." At Middlesex Ilospital, Dr. R. Boxall discoursed upon the relations existing between the public, the medical profession as a whole, and medical charities. Words of exhortation and afvice were also offered at St. Mary's Ilospitar, by Dr. S. Spicer, and at University College Ilospital, by Prof. H. R. Spencer. Miss MI. Sturge advised the students at the London School of Medicine for Women to cultivate from the first a scientific habit of mind, as its possession was invaluable 10 the medical profession. Lord Bacon's words, "We must be content to stand before nature and ask questions; nature can only be subdued by submission," were quoted as a clue to the method of work of all great physicians.

Tre Council of the In ititution of Civil Engineers has issued a long list of sabjects upon which original communications are invited. Papers upon any question of professional intercst will have their merits considered, even if they do not deal with subjects spesificl in the lis:. For approved papers the council has the p)wer to axard premiumi, arising out of special funds beq'seathed for the purpore, the particulars of which are as under:-( $t$ ) The Telford Fund, left "in trust, the interest to be expented in annual premium;, under the direction of the council." This bequejt (with accumulations of dividends) produces $£ 235$ annually. (2) The Manby Donation, of the value of about $f$ to a year, given "to form a fund for an ansual premium or premiums for papers read at the meetings." (3) The Miller Fund, bequeathed by the testator "for the parpose of forming a fund for providing premiums or prizes for the stucleats of the said institution, upon the principle of the "Telford Fund." This fund (with accumulations of diyidends) realises nearly $f_{140}$ per annum. Out of this fund the cuncil has established a scholarship, called "The Miller Scholarship of the Institution of Civil Engineers," and is prepared to award one such scholarship, not exceeding $\delta_{40}$ in valuc, each year, and terable for three years. (4) The lloward 